\title{
Popular Literary Depictions of Black African Weddings in Early Modern Spain ${ }^{1}$
}

\author{
AURELIA MARTÍN CASARES AND MARGA G. BARRANCO \\ University of Granada, Spain
}

Les caractéristiques des noirs d'Afrique sont abondamment décrites dans la littérature espagnole de la Renaissance. Ces descriptions littéraires révèlent beaucoup au sujet de l'image que l'on en avait dans les représentations collectives. La création de protagonistes et de personnages secondaires africains offre une cristallisation des observations des réalités sociales et de l'élaboration artistique de préjugés et de stéréotypes sociaux. Cet article analyse deux textes présentant des mariages de noirs d'Afrique : le premier texte est une courte pièce du XVII eiècle de Francisco de Avellaneda, et le deuxième est une ballade populaire, datant du XVIII ${ }^{e}$ siècle, et portant sur la célébration d'un mariage noir en Andalousie. Ces deux sources décrivent le mariage en se concentrant spécialement sur la dégradation des caractéristiques féminines et de la « beauté noire ».

eople of black African descent, freed or enslaved, men or women, born in Spain
or brought from Guinea, were thoroughly represented in Spanish Renaissance and Golden Age literature; they had been part of the Iberian population for centuries, and early modern authors could not, or did not want to, avoid the presence of black ${ }^{2}$ men and women in their writings. The number of plays, poems, and narratives in which sub-Saharans come into view as secondary characters, but also as protagonists, is quite surprising. Equally astonishing is the paucity of studies that have been dedicated to them by Spanish scholars and the lack of awareness of present-day Spaniards about the presence of black Africans in Castilian literature and Spanish history, particularly as Spain probably had the largest black population in Renaissance Europe. For instance, most contemporary Spaniards do not realize that the stepfather of Lázaro, the orphan rogue child who narrates his autobiography in the classic picaresque novel Vida del Lazarillo de Tormes $y$ de sus fortunas $y$ adversidades (Life of the Lazarillo de Tormes, his misfortunes and adversities, 1554), ${ }^{3}$ was a black man, even though the text is compulsory reading in secondary schools.

Paradoxically, most essays regarding black Africans in Spanish literature have been published in English. Two black scholars published the first articles on the subject in the 1930s-Carter G. Woodson ${ }^{4}$ and Velaurez B. Spratlin'5-but they 
did not become points of departure for future works. In the 1940s, an article on the specific theme of linguistic trades and phonetics of black characters in theatre was published by Edmund la Chasca. ${ }^{6}$ Later, in the 1960s, two other papers were published, the first regarding the subject of black slaves in short comedies, ${ }^{7}$ and the second centring on black characters in Golden Age Spanish literature. ${ }^{8}$ We had to wait until the 1970 s for the appearance of the compilation edited by Miriam DeCosta ${ }^{9}$ (1977) concerning not only "Spanish literature" but "Hispanic literature" as well, therefore including Latin American literary sources. Most of the authors gathered in the aforementioned volume were Afro-American scholars. Since then, in particular during the last two decades, there has been a sudden increase of publications on the issue, predominantly written by whites: British researchers, ${ }^{10}$ Spaniards, ${ }^{11}$ and Hispanophones teaching in North American universities. ${ }^{12}$ Undoubtedly, the most important volume dedicated to blacks in European history is the recent compilation edited by two British scholars, Tom Earle and Kate Lowe, entitled Black Africans in Renaissance Europe. ${ }^{13}$

Concerning the representation of black Africans in early modern Spanish literary sources, we are confronted with several contradictory images that could be grosso modo condensed into three brief snapshots. The first shows the fairly well integrated sub-Saharan freedmen who experienced similar living conditions to impoverished white Castilians. These could be represented by Lazarillo's black stepfather, ${ }^{14}$ or Luis, the stableman depicted in Cervantes' short novel El celoso extremeño (The Jealous Estremaduran). ${ }^{15}$ These role models have not been sufficiently identified or studied from historical or literary perspectives. The second depicts outstanding sub-Saharan protagonists, based on historical characters who attained their liberty due to their talents, and who were portrayed in exceptional leading roles in black comedies such as El prodigio de Etiopia (The Prodigy of Ethiopia, 1645) and the Comedia famosa del Santo Negro Rosambuco de la ciudad de Palermo (Famous Comedy of the Black Saint Rosambuco from the City of Palermo, 1612) by Lope de Vega, ${ }^{16}$ Juan Latino (John the Latin, 1645) by Diego Jiménez de Enciso, ${ }^{17}$ or El valiente negro en Flandes (The Brave Black Man in Flanders) by Andrés de Claramonte. ${ }^{18}$ These have received much attention from scholars, and their plots are summarized in several articles, but interpretations are often repeated and literary papers frequently lack the use of historical sources to contextualize slavery, using a contemporary point of view to explain these protagonists' reactions in seventeenth-century society. The third image is of ordinary black men and women, enslaved or free, depicted with incredible cruelty in popular songs and poems and used as a literary device to allow Europeans to affirm their dominance and "superiority." These kinds of sources are understudied 
since they are more difficult to locate, but they provide extremely interesting information on the construction of stereotypes in the dominant xenophobic ideology. Regarding the stereotyping of black Africans in Renaissance Europe, Kate Lowe has recently published a superb article on this topic. ${ }^{19}$

Our article ${ }^{20}$ focuses on a series of romances (poems) that evoke this third type of social representation of black African individuals, most of them anonymous but some with a recognized author. To serve our purposes, we have selected two of them, which have not yet been analyzed in the bibliography on the subject. Thus, what follows here underscores the presentation of images of sub-Saharan characters portrayed in stereotypical and remarkably negative terms. The two sources examine weddings that specifically focus on the degradation of women characters and their "black beauty." In addition, we have attempted to analyze the gendered, racialized aspects of the texts.

The Spanish folk romancero (compilation of ballads) experienced great vitality and inspired Golden Age comedies and dramas, including some romances, which have been transmitted orally even to the present day. Numerous poems incorporated parodic contents, as their aim was to satirize customs and social practices in order to amuse contemporaries with facetious descriptions of characters and situations that were perceived as humorous at that time. Black Africans, settled or born in Spain, could not control the socially constructed images and stereotypes that creative writing poured into the popular romances because they were members of marginalized social groups with no economic resources, but neither could rustic Basques, shepherds, or fools, who were also victims of lyric discrimination. An ordinary subject for well-liked romances was courtship, invoking all kinds of love affairs, including ethnic interactions. Therefore, black Africans were also central parts of romances. Indeed, one of the first black poems, signed by Rodrigo de Reynosa ${ }^{21}$ (1520), dealt with the subject of two enamoured Africans, Jorge and Comba.

In this study, we will look at the subject of black weddings in popular poems since it inspired notorious and anonymous authors. Two popular writings regarding black marriage will be analyzed: a seventeenth-century short play titled Bayle entremesado de negros (Theatrical Dance of Blacks) written by Francisco de Avellaneda and printed in Madrid (1663),22 and the Nueva relación y curioso romance, en que se refiere la celebridad, galanteo y acaso de una boda de Negros (New Narration and Curious Romance with Reference to the Unexpected Event of a Black Wedding). ${ }^{23}$ This is a romance about the celebration of a black wedding in the city of Puerto de Santa María, in the province of Cádiz, and though the author and exact date are unknown, we believe it to have been written in the eighteenth century. 
The copies we have studied for both texts are broadsheets preserved at the National Library in Madrid, without any additional information. The Nueva relación is part of popular literature, also called literatura de cordel ${ }^{24}$ (cord literature), referring to the fact that booksellers displayed these chapbooks on their stands tied with a cord. Reprints and copies were probably sold in the most important cities all over Spain.

We should mention that the celebrated poet Francisco de Quevedo y Villegas also composed a romance on a black wedding. ${ }^{25}$ It is known that Quevedo followed the style of anonymous poems that circulated openly, and attacked village people in his satires, including slaves. In his Boda de negros (Wedding of Blacks), Quevedo brings together the stereotypes that existed in contemporary literature to represent Africans, opposing black to white and bad to good, a dichotomy whose aim was to glorify Europeans. He described the wedding as "sinister," saying that "it seemed to have been arranged in hell," recurring to the frequent parallelism between black and evil. Quevedo also persistently employed abusive animal metaphors to describe black characters, comparing them to ravens, rooks, and dogs. ${ }^{26}$

A major difference between the protagonists of Quevedo's poem, Boda de negros, and those of the Nueva relación and Bayle, is that in Quevedo's text they are referred to as slaves, while the others seem to be free born or freed. At least they are not labelled as slaves, and the details enumerated about their environment and social networks also fail to indicate whether or not they were slaves. In any case, many freed blacks lived under the same conditions as the mass of beggars and impoverished citizens who packed the streets and were concentrated on the steps of churches. But since these are fictional texts, written for Spanish people to laugh at black Africans, whether they were freed or enslaved is not crucial for the delivery of the racist message. In fact, the three texts present a mocking and completely distorted vision of the unions between people of sub-Saharan origin, which reflects the unconscious imagery of the dominant negrophobic ideology.

On the other hand, marriages between slaves, no matter whether they were Moorish, sub-Saharan, or Hindi (from "Portuguese India"), were generally objected to by their owners and disapproved of within society. The reason for this is that celibacy had long been the preferred status for servants, especially for women, irrespective of whether they were free domestic workers or slaves. ${ }^{27}$ In fact, in the case of free servants, many abandoned their work when getting married since they were committed to attending to their husbands and their own homes. Consequently, being single was associated with a greater convenience or disposition, and historical sources testify that marriages between slaves were relatively rare due to the strong 
opposition of masters to the legalization of slave unions. Moreover, when slaves did marry, they did not necessarily share a household as the new spouses generally continued living separately at their respective owners' houses.

The owner's will was at variance with the dictates of Catholicism, since in theory the church was in favour of slave unions. All Catholics were free to marry, and the Council of Trent declared that slave matrimony was a divine and human right. In fact, the church required of enslaved people the same conditions as the rest of the population in order to marry (being baptized, being single, knowledge of the rudiments of faith etc.). Similarly, the Catholic church accepted marriages between free people and slaves, stating that masters should not censure slaves for this reason, nor punish them or separate the couple by selling them to different owners. Although forbidden by ecclesiastical legislation, punishment and separation of enslaved couples was, of course, a frequent custom, usually activated at the moment they expressed their desire to marry. Indeed, this is the first issue addressed in the slave marriage manuscript dossiers that we have studied. For example, the file on the marriage between María de Padilla, a black slave, and Francisco Sánchez Moreno, a free man, starts with the following formulation: "I petition that the priest of the church of San Cecilio marries us and tells the owner of María not to sell her, not to mark her with iron and not to transport her" ${ }^{28}$ Fugitive slaves were often branded; the most common sign was an S on one cheek and an I (the depiction of a nail) on the other cheek, a hieroglyphic depiction signifying sclave (es-clavo), since the word for nail in Spanish is clavo. ${ }^{29}$

The principal reasons for the masters' rejection of their slaves' marriage were economic, because marriage implied the loss of the market value of the slave. It could also mean the death of female slaves since so many died in childbirth, or increased costs as babies and small children, who were not able to work, needed to be fed. In the entremés titled Los negros (The Blacks, 1602), $3^{30}$ the owner complains of the decline of productivity of his black male slave which was due to the slave's affection for a sub-Saharan woman, saying that "recently, he has developed a notable vice because he is attached to the little black woman of my neighbour. If she goes out, he goes after her, and my neighbour is not served by his black slave and neither am I by mine." 31

The selection of partners was usually correlated with the colour of the skin, but not with ethnic origin. There was a "colour endogamy" and, therefore, blacks married blacks, mulattos tended to marry mulattos, but it did not really matter if they had completely different life experiences and backgrounds or if they did not belong to the same African ethnic group. Since most marriages were based on the similarity 
of skin colour, a marriage could take place between a slave man of sub-Saharan origin born in the Americas and a black slave woman brought to Spain from Africa when adolescent, regardless of their place of origin, which may have been Senegal or Angola. Historical data supports this; as in the case of the marriage between María de la Calle, a black berberisca (North African dark berber), and Francisco Fernández Valenzuela, a black slave from "Portuguese India" (probably a dark Tamil).32

Moreover, most marriages involving blacks took place among slave couples, with only a small percentage taking place between slaves and free Africans. The most likely to marry were freedmen and freedwomen, predominantly ladinos, which means they were born or had lived in Spain and/or Spanish colonies for a long period of time and were virtually assimilated since they spoke good Castilian. In fact, in Covarrubias's seventeenth-century dictionary, Tesoro de la lengua castellana o española (Treasury of Castilian or Spanish Language, 1611), the definition of ladino is the same as latino, changing mute $t$ for medium d: "The barbarous Spanish population learned the purity of the Roman language badly, and the ones who mastered it were called ladinos. They were looked upon as discrete and reasonable men, and that is the reason this name was given to well-respected people in any business; the Moors and foreigners who learned our language so well that we cannot differentiate them, are also called ladinos." 33 The dictionary definition clarifies the reason why Juan Latino, the protagonist of Jiménez de Enciso's play, was referred to as a ladino.

But most of the black characters involved in literary sources concerning black weddings were not ladinos; they spoke media lengua (half language), guineo, or habla de negros (black speech). ${ }^{34}$ In fact, at the beginning of the seventeenth century, the great Francisco Quevedo, aware of the importance of mastering the technique of imitating sub-Saharan accents due to the popularity of laughing at black African characters, wrote that if an author wanted to write comedies or be a poet, he would have to know guineo, changing "l" to "r" and vice versa: "como Francisco, Flancico; primo, plimo". 35 And precisely the spelling of the word primo (cousin) in Bayle allows us to distinguish between who is black, and who is not.

The habla de negros is a typical characteristic of bozales, ${ }^{36}$ which was the word used in historical documents to describe sub-Saharan people who were born in Africa and recently brought to Spain as adolescents or adults. To be sure, the Diccionario de Autoridades' (1729) definition of bozal is: "The illiterate who has to be polished. It is an epithet ordinarily used for blacks, especially if they have recently arrived from their lands, but it is also applied to rustic people. It is the contrary of ladino." 37 Consequently, bozales were not able to speak fluent Castilian and, thus, employed West African phonemes (Mandinga, Wolof, etc.) to pronounce Spanish words, which 
resulted in the foreign accent caricatured in literary works. It is obvious that most blacks were illiterate, as were the majority of the white population.

Regarding Francisco de Avellaneda, the author of the short play, Bayle, there is very little historical data-although we know that he died in Madrid in 1684, and that apart from being a playwright, he was also appointed by the king to censor comedies, and was a general chronicler of the Kingdoms of Castile and León. ${ }^{38}$ Bayle opens with a black couple holding hands, dressed in a way to provoke ridicule. The fiancée of the wedding happens to be mute and the text is a description of the faults that the groom finds in his new bride. The rest of the characters, the godparents and guests, are placed in the lowest social position through the description of their outrageous dress and the fact that they are all disabled. Indeed, they are all described as "defective"; as either lame, one-armed, left-handed, or hunchbacked. The incorporation of black Africans into a group of people with physical difficulties tells us not only about the dreadful conditions of handicapped people at the time, but also about the stereotype of blackness as a corporeal flaw. Shamefully, throughout Bayle, the characters are laughed at and put down because of their disabilities or the colour of their skin. (Mocking disabled white people was also commonplace at the time.) Moreover, all the guests want to shake the newlyweds' hands but are unable to, and the worst of each character is emphasized through their mordant commentaries about each other's disabilities.

Afterwards, the husband becomes angry and is compared to a devil (a very common association at the time). In order to pacify the wedding guests, the spouse fetches a bag of coins for his brand new wife to buy provisions for the feast: confectionery, chickpeas, sausages, radishes, marmalade, marzipan, hens, couscous, fish, wine, olive oil, etc. But much to everyone's surprise, the bag of money triggers the recovery of the wife's capacity to speak. The wife uses her new speaking ability to say that she wishes to have a wedding ceremony with all the elements of white nuptials: plates, bellows, lights and frying pans, a velvet cloak, a skirt, dresses, petticoats, brocade tissues, hair buns and stockings, among other things. ${ }^{39}$ And the husband's answer is: "Go back to being mute, how come you have spoken so much?"40 Being mute is considered throughout the short play as an optimal feminine quality. Therefore, the husband approves of the fact that his wife is mute, by saying: "Woman and without tongue, fine." ${ }^{11}$ And the verses of the godmother express the same idea: "You have a silent woman, /in these times it's plenty". $4^{2}$ But even the godfather states that the wife will be subjected to her husband "without opening her mouth" even if she does not eat for a year. ${ }^{43}$ Indeed, silence and reclusion were considered feminine virtues, with, as one might imagine, no distinction between black and white women, and 
were repeatedly noted by the Catholic moralists of the Renaissance and Baroque as feminine aspirations. ${ }^{44}$ Apart from the fact that women are not allowed to speak, the implication is that money makes mutes speak.

The text ends with the guests eating and dancing, and the black bride and groom singing the chorus: "Gurumbé, Gurumbé, Gurumbé, / it's cloudy, but it seems like it's going to rain" 45 in so-called black speech. The gurumbé, like the guineo, the cumbé, and the zarambeque, were popular black dances that we have identified in different literary and historical sources. In this respect, sub-Saharan Africans had more freedom to preserve their dances and traditions than Moors did, since a distinctive feature of the Spanish context in comparison to northern European countries was the constant Spanish fear of Muslim invasion through the Mediterranean; black Africans, by contrast, were not perceived as posing the threat of conquest or invasion. On the contrary, they were seen as simple, harmless, and innocent people. In fact, Francisco Nuñez Muley, the spokesman of the Moorish community under King Philip II, complains that sub-Saharan African dances were permitted while leilas and zambras (Arabic dances) were prohibited, observing that Guineans were "the lowest caste." 46

On the other hand, the anonymous ballad, Nueva relación, about the black wedding that takes place in the Puerto de Santa María, is a savage criticism of marriages involving people of sub-Saharan origin. This writing is far more negrophobic than in Bayle since all elements are meant to ridicule and satirize black Africans. Woodson, it seems, was right when he affirmed that from the eighteenth century on, due to the ruthless exploitation of the Spanish colonies, much bitterness developed against blacks. ${ }^{47}$ Since many ballads were "de ida y vuelta" (coming and going back and forth from the colonies to the metropolis), they could have originated in Spanish America and been transported to Spain or the other way around. It is also relevant to understand that the decline of the romancero starts in the eighteenth century, when mediocre poets who were not so admired by the general public or by the intellectual elite wrote vulgar poems, such as the ones we allude to here.

The protagonists of the Nueva relación are Tomás de Melo, who is labelled as the "famous black," and Lucía, the woman he had courted for two years before she agreed to marry him. Lucía is presented as a good dancer who knew how to sing the cumbé (a dance of African origin), and who earned her living selling roasted chickpeas, prawns, and small doughnuts or fritters, which was a common occupation for black women as suggested by paintings of the time. The wedding takes place on 28 December, which corresponds to the day of the inocentes (innocents' day), a day for laughing at people that is still celebrated today. 
The anonymous author reveals that Lucía is the "daughter of good parents, even though they were all black." 48 The godfather of the wedding is Maldonado, whose job is making chocolate, an occupation directly related to his skin colour, and the godmother, Serafina Pacheco, is said to be a black African lady famed because of her fritters. The rest of the guests are all people of sub-Saharan ancestry, living in nearby towns such as Cádiz, Sanlúcar, Jerez, Rota, and the Puerto de Santa María, all of them cities with large black populations. The fact that they earn their living, and had a house in which to celebrate the wedding and a social network that includes people living in the vicinity, indicates that they were freed or free born black Africans.

The poem gives us almost no information about Tomás, the groom, but the bride is the target of cruel mockery based on her physical appearance. In fact, Lucía's ironically celebrated "beauty" is described by comparing her with animals. Her hair is said to be so black that village people would doubt if it was from a ram, denoting that it looked like sheep's wool. ${ }^{49}$ Her forehead is depicted as big and open, and her eyebrows are not "velvety hair, since the Master forgot it". 50 The unknown author of the writing describes her eyes as the envy of cats, because they are as bright as a blazing fire in her black face. The nose is said to be short and wide, making it difficult for her to breathe. Her mouth is likened to a bag, her teeth to those of a calf, her tongue to that of a cow, her chin to a table-top; her neck is wide and short, her hands are compared with those of a bear, and she is said to have the loin of an elephant. ${ }^{11}$ And even her breasts are said to be enormous and hanging over her belly.

Clearly the author is consciously describing Lucía's African traits as being ugly. The claim that black women were attractive in the collective imagery of early modern times seems more a contemporary notion projected back in time; if black African men were marginalized in Spanish early modern literature, black women occupied the lowest rung of the social ladder.

Before the wedding takes place, a hunt is undertaken in order to obtain food for the wedding celebration, again the same theme dealt with in the seventeenth-century short Bayle. The description of the hunt is an excuse to allude repeatedly to the fact that blacks and dogs are similar and interchangeable. But the comparison of black people with dogs is not restricted to this poem or to this epoch; on the contrary, it is an ordinary association in Golden Age literature and this interjection is used in almost all romances and plays containing sub-Saharan characters. Rubio, the master of Gaspar in Simón Aguado’s Entremés de los negros, calls his slave “dog," 52 and even a white servant employs the same formula for a mulatto girl in the Entremés de los Mirones. ${ }^{53}$ Nevertheless, people belonging to religious minorities-Jews, Moors, or Protestants, but also underprivileged people in general_could be pejoratively 
called dogs, since it was a popular insult at the time. But in the case of black African people, it might be even more significant. Quevedo, a master of word play, employed an old-fashioned word, perrengue, 54 etymologically related to dog, in the Boda de negros; and, surprisingly, the 1992 edition of the dictionary of the Royal Spanish Academy still defined this word (the use of which now constitutes a racist offence) as: "A black person, since he gets hungry easily or acts like a dog." 55 This definition has been omitted in the latest editions, but it is quite shocking that it was preserved at least until the end of the twentieth century.

After the religious ceremony, during the feast, the guests indulged in a number of popular black African dances such as the zapateado (shoe clapping), minuetes de guineo (Guinean minuets), and cadena de Congo (Congo chain). Again we see the same theme of dances of African origin that were so popular in Spain and that might have left traces in Andalusian folkloric music. We agree with Kate Lowe when she states that: "European records constantly testify to the belief in black Africans' innate sense of rhythm, but also to the stereotype of black Africans unable to control their urges to make music, sing and dance, thus turning something very positive into something more negative, linked yet again to black African lack of civilisation and self-control." ${ }^{6}$ Precisely while the guests were dancing, the dramatic scene reaches its peak, because four hooded young men, most likely whites, although not revealed as such, enter furtively and steal the victuals prepared for the celebration, leaving only the bones and a written paper saying literally: "Cousins, eat these bones."

The guests run after the thieves, brandishing their swords. This is another clue which leads us to believe that the characters are free born or freed black Africans: the right to carry weapons, a right that was absolutely forbidden to slaves. During the scandal, Tomás stumbled and fell through the stairs, fracturing his leg and his head, and the guests, who pursued the thieves out into the street, were blocked by a group of soldiers. At this point, the poem achieves its xenophobic "comic" climax by degrading the characters. The bride appears to be on the floor with unkempt hair, her breast showing, a scratched face, and her bottom "in the air," and therefore uncovered. The scene is unfortunate for Lucía in that she is deprived of any kind of dignity, not being attended by a doctor, but by a veterinarian who administrates a boiling enema, which results in her dying in her own faeces. The ballad is brought to a close with laughter at the lame fiancé and his companions, who were sent to jail and ended up without honour, and supporting the behaviour of the thieves who stole the money and kept the food.

Clearly this poem is an example of the extreme racism that existed in Spain, but it also contains valuable information on the social networks of the African commun- 
ity in Andalusia. In the eighteenth century, black people residing in Cádiz, especially freed men, seemed to have a broader social network that included whites. This is the case of Antonio María Machuca, who was born in Guinea in 1725 and baptized in Seville at the age of eight. He learned to read and write Spanish, and became a music master. ${ }^{57} \mathrm{He}$ was manumitted at the age of 25 and moved to Cádiz, where he became part of a wide social network including black slaves and freed people, but also prominent white figures, such as merchants and noblemen whom he had met as the servant of the black confraternity of Cádiz. Antonio married four freed black women between 1760 and 1774, each time in a church wedding. The fact that he even had a white servant, called Juan the Galician, underlines the notion that he enjoyed a better social position than a number of white Spaniards. Consequently, envy and even fear could also have been present in the startling literary images employed in eighteenth-century poems satirizing black attempts to imitate the wedding customs of white Spaniards of the time.

Black solidarity and companionship can be also corroborated through historical sources, such as the marriage dossier of the couple Joseph de Jesús Espejo and Ana Isabel, whose story is meticulously narrated by more than 30 black witnesses, men and women, slaves and freed people, among whom was a sergeant of the black battalion of Cádiz. Both slaves were born in Cabo Verde and brought into Andalusia when they were children. Joseph came across her on several occasions, falling in love with her. He convinced a freed woman to set a date in her house and, in front of several guests, he succeeded in obtaining her marriage promise. They finally married in 1692. But Isabel Ana had not been his only lover, since Joseph had maintained a parallel relationship with another black woman, who had persistently tried to marry him using all her connections in the black community of Cádiz, but had never achieved it..$^{8}$

Nevertheless, the difficulties and obstacles that black Africans encountered in marrying, as well as the fact that their aspirations were the butt of satire, reveal the resistance that black marriage generated in white society. It seems that the backing of these unions by ecclesiastics was due to efforts to implement catholic doctrine, rather than a sincere support of the black population, since Spanish Catholics never held the flag of abolitionism as British Quakers did.

Through the study of literary depictions of black African weddings, we have attempted to outline the development of racism based on skin colour rather than on cultural differences, and to confirm the persistence of extreme racist stereotypes into the enlightened eighteenth-century. Strong racial discrimination in a society where class prejudices and social hierarchy reigned, and where underprivileged 
whites themselves had enormous difficulties in making progress, gave birth to these popular poems. The recourse to denigrating topics by early modern Spanish writers in their definition of the "other" (in this case the depiction of black Africans), such as their connection to demoniac and animal qualities, the unattractiveness of dark skin, their uncontrolled sexuality, and their association with dirtiness and scatology, are undoubtedly meant to affirm the supremacy of white Europeans.

\section{Notes}

1. We would like to thank Professor Tony Harris from the Department of English Philology (University of Granada, Spain) for kindly checking the English of this paper.

The following abbreviations have been used:

BN: Biblioteca Nacional, Madrid.

BFT: Biblioteca de la Facultad de Teología, Granada.

AHN: Archivo Histórico Nacional, Madrid.

ACEG: Archivo de la Curia Episcopal de Granada, Granada.

AMG: Archivo Municipal de Granada.

ACD: Archivo Diocesáno de Cádiz.

2. The Castilian word "negro" (black) could be used to describe people from very different cultures, religions, and nations. For a description of the groups that could be described as blacks, see: Aurelia Martín Casares, "Free and freed black Africans at the time of Spanish Renaissance," in T. F. Earle and K. J. P. Lowe, ed., Black Africans in Renaissance Europe (Cambridge: Cambridge University Press, 2005), pp. 247-60.

3. All translations of Spanish literary sources quoted in this paper have been made by the authors. Our only intention is to communicate the meanings of the verses, paragraphs, and titles used as literary sources in this article and make them understandable, but not to make any kind of erudite translation.

4. Carter G. Woodson, "Attitudes of the Iberian Peninsula in literature," Journal of Negro History 20: 2 (1935), pp. 190-243, reprinted in Blacks in Hispanic literature: Critical Essays, ed. Miriam DeCosta (Port Washington, NY: National University Publications, Kennikat Press, 1977), pp. 36-46.

5. Velaurez B. Spratlin, “The negro in Spanish literature," Journal of Negro History 19 (1934), pp. 62-71, reprinted in Blacks in Hispanic Literature, pp. 47-52.

6. Edmund de Chasca, "The phonology of the speech of the negroes in early Spanish Drama," Hispanic Review 14 (1946), pp. 323-39.

7. Juan R. Castellano, "El negro esclavo en el entremés del Siglo de Oro," Hispania 44 (1961), pp. 55-65.

8. H. M. Jason, "The negro in Spanish literature to the end of the 'siglo de Oro'," Atenea II, 3-4 (1965), pp. 13-21.

9. Miriam DeCosta, ed., Black in Hispanic Literature. Critical essays (Port Washington, NY: National University Publications, Kennikat Press, 1977). 
10. Jeremy Lawrence, "Black Africans in Renaissance Spanish Literature," Blacks Africans in Renaissance Europe, pp. 70-93.

11. See Ricardo de la Fuente Ballesteros, "El personaje negro en la tonadilla escénica del siglo XviII," Revista de Folklore 48: 4B (1984), pp. 190-96, and Ma del Carmen Fernández Ortiz, "El habla del negro en tres entremeses atribuidos a Quiñones de Benavente," Glosa 5 (1994), pp. 89-103.

12. See Baltasar Fra Molinero, La imagen de los negros en el teatro del siglo de oro (Madrid: Siglo XXI, 1995), and Enrique Martínez López, Tablero de Ajedrez. Imágenes del negro heroico en la comedia española y en la literatura e iconografía sacra del Brasil esclavista (París: Fundacao Calouste Gulbelkian, 1998).

13. Thomas F. Earle and Kate J. P. Lowe, ed., Black Africans in Renaissance Europe (Cambridge: Cambridge University Press, 2005).

14. We do not agree with the forced victimization of this character argued in Baltasar Fra Molineo, "El negro Zaide: marginación social y textual en el Lazarillo," Hispania 76:1 (1993), pp. 20-29.

15. The character of Luis has not received much attention. For a summary of the short novel in English, see Woodson.

16. BN: R 23590. Obras de Lope de Vega publicadas por la Real Academia Española, 15 vols. (Madrid: Establecimiento Tipográfico Sucesores de Rivadeneyra, 1890-1913), vol. 4, pp. 362-92.

17. Diego Ximenez de Enciso, El Encubierto y Juan Latino. Comedias de Diego Ximénez de Enciso (1652; Madrid: Aldus, 1951).

18. Andrés de Claramente, "El valiente negro en Flandes," in Dramáticos contemporáneos de Lope de Vega, Ramón de Mesonero Romanos, ed., 2 vols. (Madrid: Atlas, 1951), vol. 1, pp. 491-509.

19. Kate Lowe, "The stereotyping of black Africans in European Renaissance," in Black Africans in Renaissance Europe.

20. This article forms part of a long-term, interdisciplinary research project financed by the Spanish Ministry of Education entitled "Black Africans and their descendants in Spain: 1492-1886" at the University of Granada in Spain. Our research team is systematically gathering imagery, literary texts, and historical documents and crossreferencing the different sources in order to record the life and experiences of black Africans in Spain from an interdisciplinary perspective that includes history, anthropology, literature, and art. Up to now, we have gathered more than a hundred literary texts printed in Spain between the sixteenth and eighteenth centuries that portray black African characters, men or women. We are also working on nineteenth-century Cuban and Puerto Rican literary sources, trying to understand the abolition process and its ethnic implications.

21. BN: R. 9468. Rodrigo de Reynosa, Comiençan unas coplas a los negros y negras: $y$ de cómo se motejavan en Sevilla un negro de Gelofe Mandinga contra una negra de Guinea. A el llamavan Jorge: y a ella Comba: $i$ como el la requeria de amores: y ella dezia que tenia otro enamorado que llamavan Grisolmo. Cantanse al tono de la niña quando baileis. For 
a discussion of the poem, see Lawrence; also, see Peter E. Russell, "La 'poesía negra' de Rodrigo de Reynosa," in Temas de la Celestina y otros estudios: del Cid al Quijote (Barcelona: Ariel, 1978), pp. 377-406.

22. BN: R. 6355. Francisco de Avellaneda, Bayle entremesado de negros (Madrid: Andrés García de la Iglesia, 1663), pp. 67-70.

23. BN: VE/1348/15.

24. Julio Caro Baroja, Ensayo sobre la Literatura de Cordel (Madrid: Revista de Occidente, 1969).

25. BN: R. 39212. Francisco de Quevedo, "Boda de negros," in El Parnasso español, monte de dos cumbres dividido, con las nueve musas castellanas, donde se contienen poesías de Don Francisco de Quevedo Villegas, Cavallero de la Orden de Santiago, y Señor de la Villa de la Torre de Juan Abad. Salen aora añadido con adorno de unas Dissertaciones a cada una de las Musas (Madrid: Imprenta y Librería de Don Pedro Joseph Alonso de Padilla, 1729), pp. 499-500.

26. "Iban los dos de las manos, / como pudieran dos cuervos; otros dicen, como grajos, / porque a grajos van oliendo" (They hold hands, / as two ravens; others say as rooks,/ because they smell like rooks).

27. Aurelia Martín Casares, "Domestic service in Spain: Legislation, gender and social practice," in Domestic Service and the Formation of the European Identity: Understanding the Globalization of Domestic Work. 16th-21st centuries, Antoinette FauveChamoux, ed. (New York-Bern: Peter Lang, 2004), pp. 189-209.

28. ACEG, item 1579-1585.

29. For a study of slave marks and tatoos, see Aurelia Martín Casares, "El herraje y los tatuajes," in La esclavitud en la Granada del siglo XVI: género, raza y religión (Universidad de Granada: Granada, 2000), pp. 390-97.

30. Simón Aguado, "Entremés de los negros," Revista de Archivos, Bibliotecas y Museos, (1901), pp. 912-19.

31. "de unos días acá ha dado un notable vicio, y es que se me ha aficionado de una negrilla en un vecino mío. Si va la negra fuera, él va tras ella, y ni el otro se sirve de su negra ni yo de mi negro."

32. ACEG, item 1605-B.

33. Sebastián de Covarrubias Orozco, Tesoro de la lengua castellana (Madrid: Taurus, 1984).

34. Consolación Baranda Letuario, "Las hablas de negros. Orígenes de un personaje literario,” Revista de Filología Española, 69 (1989), pp. 311-33. Pilar Sarró López, "Notas sobre la morfosintaxis del habla de las negras de Lope de Rueda," in Actas del Primer Congreso Internacional de Historia de la Lengua Española, Manuel Ariza, Antonio Salvador, and Antonio Viudas, ed. (Madrid: Arco Libros, 1987), pp. 601-10.

35. BFT, AQ 16f, 1661. Francisco de Quevedo, "Libro de todas las cosas y otras muchas más," in Obras de Don Francisco de Quevedo Villegas (Bruselas: Imprenta de Francisco Foppens, 1661), pp 583-96. 
36. See chapter on "bozales y ladinos" in Aurelia Martín Casares, La esclavitud, pp. $155-57$.

37. Diccionario de Autoridades, Biblioteca Románica Hispánica (Madrid: Gredos, 1990), p. 666.

38. Gema Cienfuegos Antelo, El teatro breve de Francisco de Avellaneda: estudio y edición (Madrid: Fundación Universitaria Española, 2006).

39. "avra escudirias, pratos, / un manto de terciopelo, / basiquiña de damasco, / vistidos, poyeras, sayas, / saldirin de bolocado, / tampa pieça de esteriya / cu lechones, quando echamo / cariria con poyera, / un justiyo curcerado, / fueyes, candeya, assadora, / moño, medias, y essepatos."

40. "Volveos a ser muda, ¿cómo habéis hablado tanto?"

41. "Mujer y sin lengua, bueno."

42. "Vos tenéis muger callada, / que en estos tiempos es harto."

43. "a vos estará sujeta,/que humilde a vuestro mandato,/ no dirá esta boca es mía,/ aunque no coma en una año."

44. Aurelia Martín Casares, "Las mujeres y la paz en la casa en el discurso renacentista,"Chronica Nova 29 (2002), pp. 217-44.

45. "Gurumbé, gurumbé, gurumbé, / que faze nubrado, y quiere llove."

46. R. Foulche-Delbosc, "Memorial de Francisco Núñez Muley," Revue Hispanique (1899), pp. 205-39.

47. Woodson, p.46.

48. "es hija de buenos padres, / aunque todos fueron negros."

49. "que ha dudado el Pueblo, si es de carnero merino, / o si es del Sol el paseo."

50. "no son de terso pelo / porque ésto se le quedó, / al Maestro en el tintero."

51. "Su boca parece bolsa / los dientes como becerro, / la lengua como una baca, / la barba como un tablero; / el pescuezo gordo y corto; / pero largo en los fideos.”

52. "Pues perro... ¿no sabes que eres mi esclavo?" (So, dog ... don't you know you are my slave?), in Aguado, Entremés de los negros.

53. “ijusticia de Dios! ¡Perra mulata, el señor corregidor sabrá corregir esta maldad!”, in Miguel de Cervantes, "Entremés de los Mirones," in Varias obras inéditas de Cervantes, sacadas de códices de la Biblioteca Colombina, con nuevas ilustraciones sobre la vida del autor y El Quijote, Adolfo de Castro, ed. (Madrid: A. de Carlos e hijo, 1874), p. 39.

54. "que le abrasaban las pulgas, por perrengues o por perros" (flies flamed them, because of being dogs).

55. Diccionario de la Lengua Española (Madrid: RAE, 1992), p. 158.

56. Lowe, "The stereotyping of black Africans," p. 35.

57. ACD, Expedientes matrimoniales, item 421, 1774. Cited by Alessandro Stella, Histories d'esclaves dans la péninsule ibérique, (París, EHESS, 2000), p. 124.

58. ACD, Varios, Divorcios, item 577, 1693. Cited by Alessandro Stella, p. 119. 